\title{
Atopic NC/Nga Mice as a Model for Allergic Asthma: Severe Allergic Responses by Single Intranasal Challenge with Protein Antigen
}

\author{
Tadashi IWASAKI ${ }^{1,2)}$, Akane TANAKA ${ }^{2)}$, Atsuko ITAKURA ${ }^{2)}$, Naomi YAMASHITA ${ }^{3)}$, Ken OHTA ${ }^{3)}$, \\ Hiroshi MATSUDA $^{2)}$ and Misao ONUMA ${ }^{1) *}$ \\ ${ }^{1)}$ Laboratory of Infectious Diseases, Department of Disease Control, Graduate School of Veterinary Medicine, Hokkaido University, \\ Sapporo 060-0818, ${ }^{2}$ Laboratory of Clinical Immunology, Department of Veterinary Clinic, Faculty of Agriculture, Tokyo University of \\ Agriculture and Technology, Fuchu, Tokyo 183-8509 and ${ }^{3)}$ Department of Medicine, Teikyo University School of Medicine, 2-11-1 Kaga, \\ Itabashi-ku, Tokyo 173-8605, Japan
}

(Received 8 November 2000/Accepted 25 December 2000)

\begin{abstract}
Since certain characters of allergic asthma are common with other allergic disorders like atopic dermatitis, the possible relationship in etiology is expected. Herein, we investigated whether $\mathrm{NC} / \mathrm{Nga}$ mice, an inherent animal model for human atopic dermatitis, are inclined to allergic asthma. A single intranasal challenge of $\mathrm{NC} / \mathrm{Nga}$ mice immunized with ovalbumin (OVA) resulted in an increase in plasma levels of OVA-specific IgE, and typical pathological aspects of allergic asthma characterized by infiltration of numerous eosinophils, mucus hyper production of bronchial epithelial cells. Moreover, airway hyperresponsiveness to inhaled acetylcholine and marked enhancement of airway resistance after the challenge were observed as compared to control BALB/c mice. Delayed expression of mRNA of eosinophil active chemokines, interleukin-5, eotaxin, macrophage inflammatory protein-1 $\alpha$ in concert with eosinophilia was determined in the lung of $\mathrm{NC} / \mathrm{Nga}$ mice. These results suggest that asthmatic responses developed in NC/Nga mice challenged with OVA are very similar to human allergic asthma, and that $\mathrm{NC} / \mathrm{Nga}$ mice are a useful model to elucidate various aspects of allergic asthma. KEY WORDS: allergy, cytokine, eosinophil, in vivo animal model, lung.
\end{abstract}

Allergic asthma is a chronic obstructive disease of the lower airways in children and young adults with an individual or family history of allergic or atopic diseases, and is characterized by severe eosinophilic inflammation, reversible airflow limitation, airway hyperresponsiveness, relapsing paraxysms of wheezing, cough, and dyspenia [3, 9]. Investigations of the cytohistological aspects of the lung in patients and experimentally-induced asthma models indicate that a chain of immunological reactions based on a complicated interaction between various kinds of inflammatory cells, chemical mediators, and cytokines, lead to dysfunction of the lower airways with marked pathological changes such as occlusion with mucus, edema, leukocyte infiltration with eosinophils predominating, epithelial damage, exposure of sensory nerve endings, and hypertrophy of the smooth muscle $[2,12]$. Many researchers accept that there is a strong association between eosinophil numbers in the tissue or their state of activation and the severity of asthma [4, 25]. Eosinophils are a major population in inflammatory cells infiltrated into the lung tissue, and eosinophil granule proteins such as major basic protein and eosinophil cationic protein, damage the tissue structure and functions [7, 16]. Such inflammatory reactions are driven by networks of several factors categorized as Th2 cytokines, such as interleukin (IL)-4, and IL-5 [13, 19]: especially IL-5 is a key potentiator for growth, differentiation, and functions of eosinophils [6]. In addition to IL-5, certain chemoattrac-

\footnotetext{
* Correspondence to: Onuma, M., Laboratory of Infectious Diseases, Department of Disease Control, Graduate School of Veterinary Medicine, Hokkaido University, Sapporo 060-0818, Japan
}

tants for eosinophils such as eotaxin, RANTES (regulated on activation, normal T-cell expressed and secreted), and macrophage inflammatory protein- $1 \alpha$ (MIP-1 $\alpha)$ which were detected in bronchoalveolar lavage (BAL) fluid from patients with asthma and from experimentally-induced allergic asthma models, are considered to be involved in the pathogenesis of allergic asthma [1,20].

Recently, we have demonstrated that inbred NC/Nga mice are useful as an animal model for human atopic dermatitis [14, 15, 27]. Skin lesions with increased numbers of eosinophils, mast cells, CD4 ${ }^{+} \mathrm{T}$ cells, and macrophages, which were clinically and histologically very similar to human atopic dermatitis, spontaneously developed in $\mathrm{NC} /$ $\mathrm{Nga}$ mice with a marked elevation in plasma levels of total $\mathrm{IgE}$ when raised in air-uncontrolled conventional circumstances, but not when raised in air-controlled specific pathogen-free conditions. Epidemiological analysis shows a high incidence of asthma and/or allergic rhinitis in the majority of infants and children with a history of atopic dermatitis [21]. Therefore, there is a possibility that NC/Nga mice have some inherited character(s) which predispose to allergic asthma as well as atopic dermatitis. In the present study, we demonstrated that single intranasal challenge with ovalbumin (OVA) to immunized NC/Nga mice led to severe and prolonged eosinophilic inflammation in the lung with asthmatic aspects including increased plasma levels of antigen $(\mathrm{Ag})$-specific IgE. In addition, these mice revealed airway hyperresponsiveness to inhaled acetylcholine and marked enhancement of airway resistance after the Ag challenge. 


\section{MATERIALS AND METHODS}

Mice: Specific pathogen-free NC/NgaTnd mice, BALB/c mice, and Wistar rats were obtained from Charles River Japan Inc. (Kanagawa, Japan). Animal experiments complied with the standards in the guidelines of the University Animal Care and Use Committee in Tokyo University of Agriculture and Technology.

Immunization and challenge: Mice were injected i.p. with $200 \mu \mathrm{l}$ of saline containing $100 \mu \mathrm{g}$ of OVA (Sigma Chemical Co., St. Louis, MO) absorbed in $1.6 \mathrm{mg}$ of alum. This immunization with OVA/alum was conducted in mice by two injections, 1 and 2 weeks before challenge. OVAimmunized and nonimmunized control mice were challenged by an intranasal administration of $50 \mu \mathrm{l}$ of saline containing $10 \mu \mathrm{g}$ of OVA under pentobarbital sodium anesthesia. At various hours following the antigen challenge, most of whole blood in mice anesthetized with pentobarbital sodium was taken off by heart puncture, and a cannula was immediately inserted into the trachea. The collected blood was heparinized, and plasma samples were stored at $-80^{\circ} \mathrm{C}$ until quantitative analysis for a passive cutaneous anaphylaxis (PCA) reaction. BAL fluid was collected by gently washing with $500 \mu l$ of phosphate-buffered saline (PBS) four times. The supernatants were snap frozen in liquid nitrogen and stored at $-80^{\circ} \mathrm{C}$ for various analyses. Cells separated from the BAL fluid were counted for total cell numbers, and Diff Quick-stained cytospin preparations were made for cell differentiation.

Assessment of airway responsiveness: Airway reactivity to acetylcholine was measured according to the method reported previously [17]. Briefly, under pentobarbital sodium anesthesia, the mice were intubated, ventilated at the rate of 120 breaths/min with a constant tidal volume of air $(0.5 \mathrm{ml})$ using a Harvard Instruments ventilator, and paralyzed with pancuronium bromide. The mice were then placed into whole-body plethysmographs (Buxo Electronics, Troy, NY) to measure airway resistance. Increasing doses of acetylcholine and $20 \mathrm{mg} / \mathrm{m} l$ OVA were administered by ultranebulization for $3 \mathrm{~min}$ and $10 \mathrm{~min}$, respectively. Changes in airway resistance induced by acetylcholine and OVA are expressed as the percent change from the airway resistance observed prior to the inhalation of acetylcholine and OVA.

$P C A$ reaction: OVA-specific IgE levels were determined by a PCA reaction [28]. Intradermal injection of $100 \mu \mathrm{l}$ of 2 -fold diluted plasma samples was carried out into the shaved skin of the trunk in Wistar rats. One day later the rats were challenged with an i.v. injection of $1.0 \mathrm{~m} l$ of a saline solution containing $1 \mathrm{mg} / \mathrm{ml} \mathrm{OVA}$ and $1 \%$ Evans blue. After $30 \mathrm{~min}$, a positive reaction with dye infiltration was evaluated, and PCA titers were expressed as $\log _{2}$ titer of the reciprocal of the highest dilution of plasma samples providing a PCA reaction.

Measurement of tissue eosinophil-peroxidase (EPO) activity: To quantitative inflammatory cells infiltrated into the lung, we estimated tissue levels of EPO reflecting the presence of eosinophils [26]. At various hours after the challenge, a lobe of the lung was cut off and homogenized in $2 \mathrm{~m} l$ of $50 \mathrm{mM}$ potassium phosphate containing $0.5 \%$ hexadecyl-trimethylammonium bromide. The specimens were centrifuged and $50 \mu l$ of supernatants were mixed with 100 $\mu l$ of substrate solution $[50 \mathrm{mM}$ Tris- $\mathrm{HCl}(\mathrm{pH} 8.0), 0.1 \%$ Triton X-100, $1 \mathrm{mM} o$-phenylenediamine, and $0.5 \mathrm{mM}$ $\mathrm{H}_{2} \mathrm{O}_{2}$ ]. After incubation for $30 \mathrm{~min}$ at room temperature, 50 $\mu l$ of $2 \mathrm{~N} \mathrm{H}_{2} \mathrm{SO}_{4}$ was added to stop reaction. An EPO activity was measured as an absorbance at $490 \mathrm{~nm}$ wave length.

Histological examination: At $24 \mathrm{hr}$ after the challenge, the lungs were excised and flushed and fixed with $10 \%$ buffered formalin ( $\mathrm{pH}$ 7.2). Lung tissues were embedded in paraffin and cut at $5 \mu \mathrm{m}$; and the sections were deparaffinized, rehydrated, and stained with hematoxylin and eosin for evaluating airway inflammation and stained with $0.1 \%$ alcian blue ( $\mathrm{pH} 2.5)$ and periodic acid-Schiff for acidic mucin and sulfated mucosubstances.

RNase protection assay (RPA): Total RNA from lung tissues was extracted at different time intervals using ISOGEN (Nippon Gene, Tokyo, Japan). Chemokine mRNA expression was determined by a multiprobe RPA using a RiboQuant RPA kit (PharMingen, San Diego, CA). The identity and quantity of each mRNA species in the original RNA samples were determined based on the intensity of protected probe fragment bands. The loaded samples were normalized by a housekeeping gene, L32, included in each template set.

Statistical analysis: Statistical significance was determined using Student's $t$ test.

\section{RESULTS}

Airway resistance: To estimate the inclination to asthma in $\mathrm{NC} / \mathrm{Nga}$ mice and BALB/c mice, airway responsiveness to inhaled acetylcholine, which is one of the most important risk factors of the disease $[10,11]$, was assessed. When two concentrations of acetylcholine $(250$ and $500 \mu \mathrm{g} / \mathrm{ml})$ were inhaled, hyperreactivity to acetylcholine was noted in $\mathrm{NC} /$ $\mathrm{Nga}$ and BALB/c mice immunized with OVA; the bronchial response of $\mathrm{NC} / \mathrm{Nga}$ mice was approximately 5-fold higher than that of BALB/c mice at the individual doses (Fig. 1A). Next, we evaluated airway resistance at 6 and $24 \mathrm{hr}$ after the challenge with OVA. As shown in Fig. 1B, bronchial resistance was increased at $6 \mathrm{hr}$ in both strains of mice. Twenty four hours later, the bronchial resistance of $\mathrm{NC} / \mathrm{Nga}$ mice retained high levels, whereas the resistance level in BALB/ c mice was decreased by about $50 \%$ as compared that at 6 hr.

Anti-OVA IgE levels: Plasma levels of OVA-specific IgE, which is another risk factor for asthma and reported to correlate with airway susceptibility in human subjects [18, 22], were assayed one week after the second immunization. The immunization with OVA resulted in a significant increase in OVA-specific IgE levels in NC/Nga mice, as compared with those in $\mathrm{BALB} / \mathrm{c}$ mice ( $\log _{2}$ value, $5.56 \pm 0.26$ versus $2.40 \pm$ 0.06 respectively; $p<0.01)$. 
A

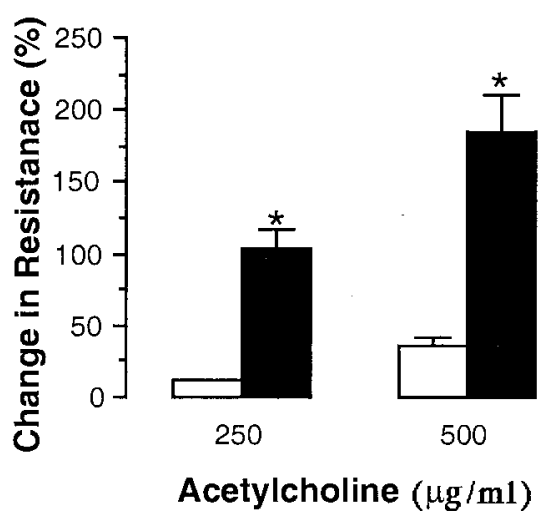

B

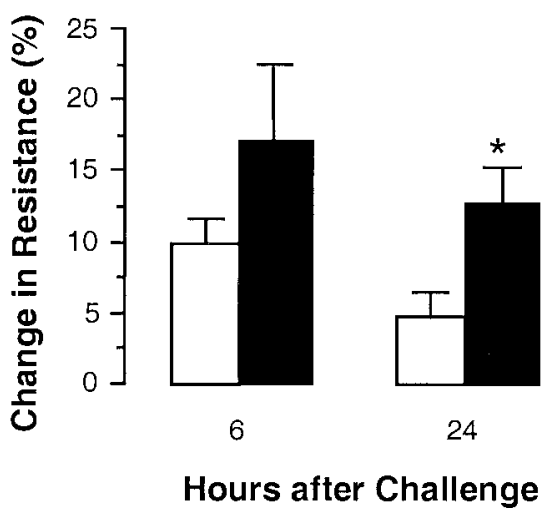

Fig. 1. Airway reactivity to acetylcholine (A) and airway resistance (B) after the challenge with OVA. Change in airway resistance after application of two concentrations $(250,500 \mu \mathrm{g} / \mathrm{m} l)$ of acetylcholine was measured 1 week after the second immunization. Airway resistance was measured at $24 \mathrm{hr}$ after the intranasal challenge. Closed (NC/Nga mice) and open (BALB/c mice) bars represent the mean $\pm \mathrm{SE}$ of three separate experiments. $* p<0.01$, when compared with BALB/c mice.

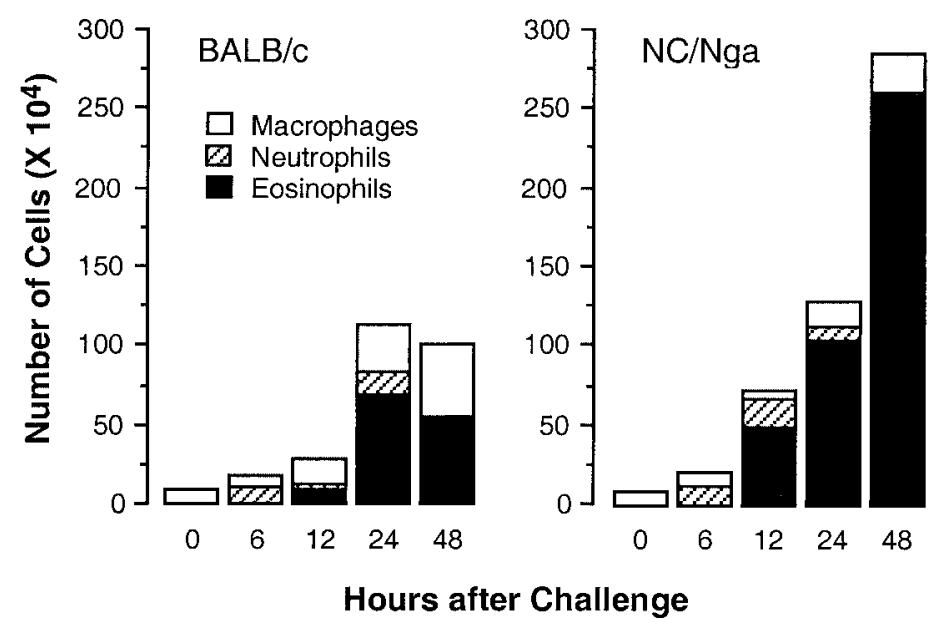

Fig. 2. Numbers of macrophages, neutrophils, and eosinophils in BAL fluid collected from BALB/c mice and NC/Nga mice after the challenge. Each point represents the mean value of five separate experiments.

Cell populations in BAL fluid: To characterize the airway inflammation, at various hours after the challenge with OVA inflammatory cells in the BAL fluid were differentiated and enumerated (Figs. 2 and 3). In both strains of mice, a slight increase in the number of cells, mainly neutrophils and macrophages, was detected at $6 \mathrm{hr}$; and at $12 \mathrm{hr}$ numerous eosinophils were detected, but their number in NC/Nga mice was 3-fold higher than that in BALB/c mice. In BALB/ $\mathrm{c}$ mice, the number of eosinophils reached a maximal level at $24 \mathrm{hr}$ and their number was slightly decreased at $48 \mathrm{hr}$; and macrophages were also predominant at $24 \mathrm{hr}$ and their number peaked at $48 \mathrm{hr}$. On the other hand, in NC/Nga mice their infiltration into the alveolar bronchi extremely progressed even until $48 \mathrm{hr}$, whereas the number of macroph- ages was slightly increased during the period of $48 \mathrm{hr}$.

Eosinophil numbers in the peripheral blood: Since the increased eosinophil progenitors in the bone marrow contribute to the subsequent development of blood and tissue eosinophilia after the provocation with Ag [23], we counted the number of eosinophils in the peripheral blood after the intranasal application with OVA. The immunization of $\mathrm{NC} /$ Nga mice with OVA resulted in an increase in eosinophil numbers more than 3.5 times as compared with nonimmunized control NC/Nga mice (Fig. 4). A drastic increase in eosinophil numbers was observed following a rapid and temporary decline at $6 \mathrm{hr}$ after the challenge. In BALB/c mice, until $12 \mathrm{hr}$ after the challenge the change in the number of eosinophils showed roughly comparable to that in 
$12 \mathrm{hr}$
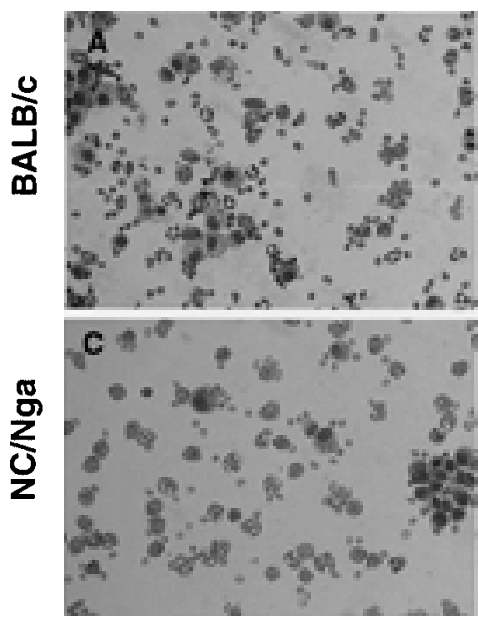

$24 \mathrm{hr}$
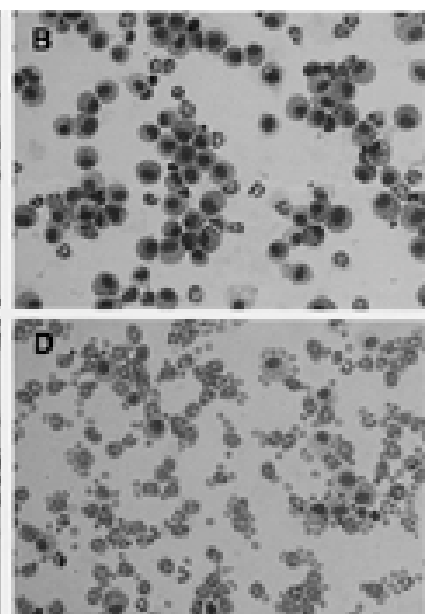

Fig. 3. Cytospin preparations of BAL cells at 12 and $24 \mathrm{hr}$ after the challenge of BALB/c mice and NC/Nga mice with OVA. In NC/Nga mice numerous degranulated eosinophils are obvious at 12 and $24 \mathrm{hr}$ later. In BALB/c mice, at $12 \mathrm{hr}$ eosinophils, neutrophils, and macrophages are observed and at $24 \mathrm{hr}$ macrophages are predominant. Cytospin preparations were stained with Diff Quick. Original magnification: 320.
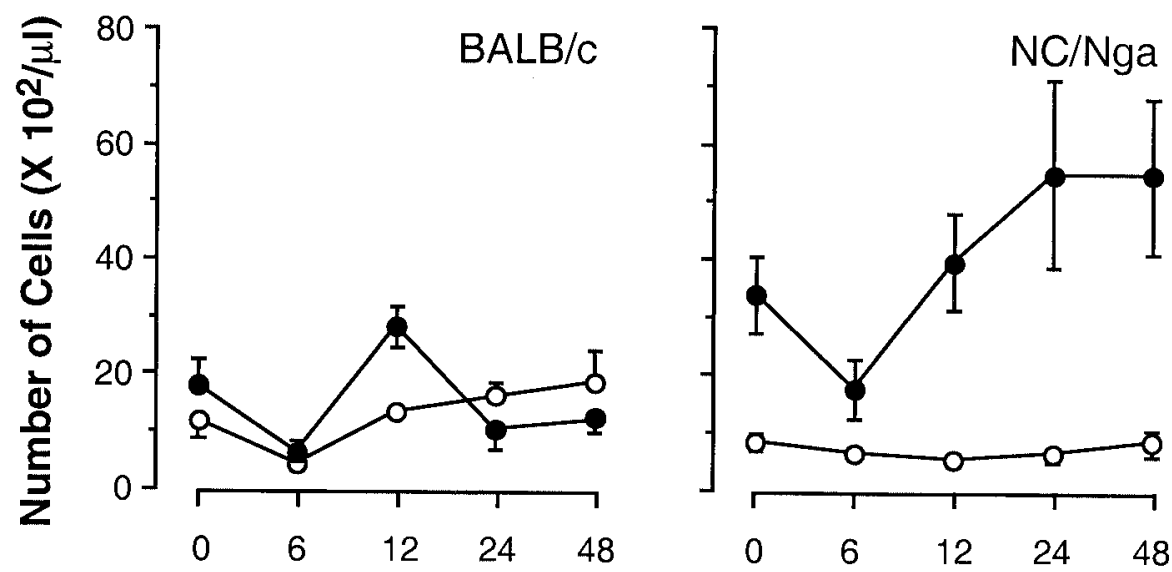

\section{Hours after Challenge}

Fig. 4. Number of eosinophils in the peripheral blood at various hours after the challenge of BALB/c mice and NC/Nga mice with OVA. Immunized (closed) and nonimmunized (open) mice were intranasally challenged with OVA. Each point represents the mean \pm SE of five separate experiments.

$\mathrm{NC} / \mathrm{Nga}$ mice, but their numbers returned to control levels at $24 \mathrm{hr}$ (Fig. 4).

Lung tissue damage after the OVA challenge: The infiltration of eosinophils and neutrophils into lung tissues was estimated by enzymatic quantitative assessment and histological analysis. First, EPO was measured at various hours after the intranasal challenge with OVA. Before the appearance of eosinophils in the BAL fluid, an EPO activity in lungs of both the strains of mice was detected at $6 \mathrm{hr}$; and the levels were much higher in $\mathrm{NC} / \mathrm{Nga}$ mice, and extremely increased even until $48 \mathrm{hr}$, whereas in BALB/c mice the EPO activity was decreased at $48 \mathrm{hr}$ (Fig. 5). Next, histolog- 


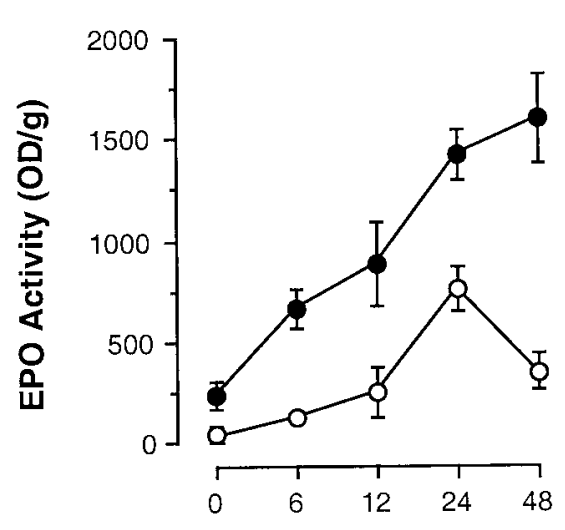

Hours after Challenge

Fig. 5. EPO activity in lungs after the challenge with OVA. Lungs were removed from $\mathrm{BALB} / \mathrm{c}$ mice (open) and NC/Nga mice (closed), and homogenized and centrifuged. EPO activities in the supernatants were determined as described in Materials and Methods. Each point represents the mean \pm $\mathrm{SE}$ of four to eight separate experiments.

ical examination was performed on the lung at $24 \mathrm{hr}$ after the challenge. Active immunization of NC/Nga mice with OVA induced very intensive infiltration of eosinophils into the lung parenchyma and alveoli with severe tissue damage, and most of the bronchial epithelial cells contained mucus glycoproteins which were stained with alcian blue and PAS (Fig. 6). In contrast, BALB/c mice revealed faint accumulation of eosinophils and macrophages in the lung tissues, and little positive reaction for mucus glycoproteins was observed in the bronchial epithelium at $24 \mathrm{hr}$ (Fig. 6), whereas the bronchial epithelial cells were positive for alcian blue/PAS at $12 \mathrm{hr}$. No or little pathological changes were detected in the lung of nonimmunized control mice after the challenge.

mRNA expression of chemokines: To clarify the possible production of chemokines and a cytokine involved in eosinophil production and infiltration into the lung, we estimated mRNA levels of eotaxin, RANTES, MIP- $1 \alpha$, and IL5 in lung tissues by a RPA. Tissue samples were collected at various hours after the intranasal challenge with OVA. Although there was no significant difference in mRNA expression levels of eotaxin, RANTES, and MIP- $1 \alpha$ between $\mathrm{NC} / \mathrm{Nga}$ and $\mathrm{BALB} / \mathrm{c}$ mice, peak levels were noted $6 \mathrm{hr}$ and $24 \mathrm{hr}$ after challenge in BALB/c and NC/Nga mice respectively (data not shown). For cytokine IL-5, the maximum level was noted $24 \mathrm{hr}$ after the challenge in both mice strains (data not shown).

\section{DISCUSSION}

Much is known regarding how eosinophils markedly and widely infiltrated in the lower airway play a crucial role in

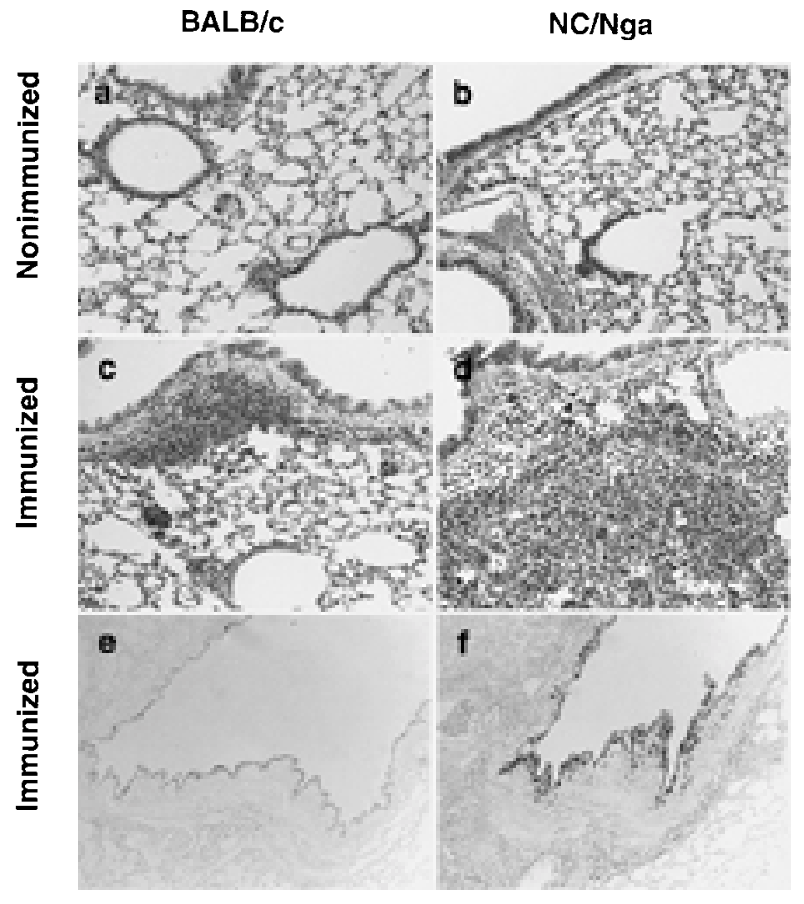

Fig. 6. Histological features of lungs at $24 \mathrm{hr}$ after the challenge. Immunized and nonimmunized mice were intranasally challenged with OVA. In NC/Nga mice, marked infiltration of eosinophils into the lung parenchyma and alveoli with severe tissue damage (d) and alcian blue/PAS-positive bronchiolar epithelial cells (f) are marked. In contrast, faint accumulation of eosinophils and macrophages in the lung tissues (c) and little positive reaction for mucus glycoproteins in the bronchiolar epithelium (e) are observed. No or little pathological changes are detected in the lung of nonimmunized control mice ( $a$ and $b$ ). Sections were stained with Congo red and with alcian blue and PAS. Original magnification: 160 .

sophisticated pathogenesis of allergic asthma [24, 25]. In experimentally-induced asthma models using standard inbred strains of rodents, the eosinophil response and airway hyperresponsiveness to acetylcholine or methacholine are induced, but the grade of the phenomena is generally limited. In the present study, we clearly demonstrated that NC/ Nga mice exhibited higher susceptibility to the development of OVA-induced airway inflammation: widely and prolonged eosinophilic inflammation accompanied by marked and prolonged enhancement of airway resistance and hyperresponsiveness to acetylcholine after the single intranasal challenge with OVA. NC/Nga mice are an inbred strain that manifests atopic dermatitis-like skin lesions including marked infiltration of eosinophils and $\mathrm{CD} 4{ }^{+} \mathrm{T}$ cells, numerous degranulated mast cells and macrophages [14], and overexpression of Th2 chemokines [27], which may be triggered by some environmental factor(s). In addition to dermatitis, IgE hyperproduction is induced with progression of the disease $[14,15]$. These pathological aspects give rise to a possibility that $\mathrm{NC} / \mathrm{Nga}$ mice have some inherited risk 
character(s) for allergic asthma including IgE hyperproduction, and are a suitable model for the human disease. In fact, i.p. injections with antigen led to higher production of Agspecific IgE in NC/Nga mice, as compared with that in $\mathrm{BALB} / \mathrm{c}$ mice. In this study, we employed the one-weekinterval protocol, since in our preliminary experiment, twoweek-interval protocol induced much higher production of Ag-specific IgE, resulting in anaphylactic death of NC/Nga mice.

Eosinophilic inflammation which appeared in $\mathrm{NC} / \mathrm{Nga}$ mice was not only severe but also prolonged. This seems to be caused by two step mechanisms: increased number of eosinophil progenitors in the bone marrow pool and a strong attraction signal for eosinophil infiltration from blood stream into the affected tissue site. Increased number of blood eosinophils in $\mathrm{NC} / \mathrm{Nga}$ mice suggests a possible supplement of eosinophil progenitors in the bone marrow pool after the OVA challenge. In asthmatic patients with late asthmatic response, remarked supply of eosinophil progenitors after the challenge has been found [23]. Analysis for mRNA expression of eosinophil active chemokines in lungs demonstrated another aspect of NC/Nga mice: delayed expression of mRNA of eotaxin, and MIP- $1 \alpha$ mRNA, but not RANTES. These chemokines are known as a chemotactic agent for eosinophils and reported to be increased in BAL fluid of asthmatic patients [1]. Especially, eotaxin, which is a specific chemotactic factor for eosinophils, has some other functions: enhancement of adhesion to endothelium [5] and activation of respiratory burst of the cells [8]. Thus, we consider that the prolonged expression of chemokines which concerts with massive supply of eosinophils from the bone marrow pool may be involved in severe eosinophilic inflammation in NC/Nga mice.

Since bioactive materials including the major basic protein, EPO, eosinophil cationic protein, and eosinophilderived neurotoxin, released from eosinophils at the affected site are recognized to seriously affect airway functions; promotion of bronchospasm, an increase in bronchoreactivity to acetylcholine, and damage to the bronchial epithelium $[4,7,16]$, numerous eosinophils infiltrated into the lung tissues may play a key cell population to induce the asthmatic change observed in NC/Nga mice.

Taken together, the experiments presented here strongly indicated that $\mathrm{NC} / \mathrm{Nga}$ mice are a very suitable model for allergic asthma characterized by allergic inflammatory responses including massive and prolonged eosinophilic infiltration, and $\mathrm{Ag}$-specific IgE production. Importantly, $\mathrm{NC} / \mathrm{Nga}$ mice expressed higher airway hyperresponsiveness to acetylcholine and marked enhancement of airway resistance after the single Ag challenge, as compared with $\mathrm{BALB} / \mathrm{c}$ mice. Thus, we consider that $\mathrm{NC} / \mathrm{Nga}$ mice are a very useful tool to investigate the pathogenesis of allergic asthma, and to develop new approaches to the therapy.

ACKNOWLEDGEMENTS. This work was supported by grants from the Ministry of Education, Science, Sports, and Culture, Japan; for Specially Promoted Research on Atopic
Disorders from the Tokyo Metropolitan Government; and from the Pioneering Research Project in Biotechnology provided by the Ministry of Agriculture, Forestry, and Fisheries, Japan.

\section{REFERENCES}

1. Alam, R., York, J., Boyars, M., Stafford, S., Grant, J. A., Lee, J., Forsythe, P., Sim, T. and Ida, N. 1996. Increased MCP-1, RANTES, and MIP- $1 \alpha$ in bronchoalveolar lavage fluid of allergic asthmatic patients. Am. J. Respir. Crit. Care Med. 153: 1398-1404.

2. Arm, J. P. and Lee, T. H. 1992. The pathology of bronchial asthma. Adv. Immunol. 51: 323-382.

3. Bochner, B. S., Undem, B. J. and Lichtenstein, L. M. 1994. Immunological aspects of allergic asthma. Annu. Rev. Immunol. 12: 295-335.

4. Brofman, J. D., White, S. R., Blake, J. S., Munoz, N. M., Gleich, G. J. and Leff, A. R. 1989. Epithelial augmentation of trachial contraction caused by major basic protein of eosinophils. J. Appl. Physiol. 66: 1867-1873.

5. Burke-Gaffney, A. and Hellewell, P. G. 1996. Eotaxin stimulates eosinophil adhesion to human lung microvascular endothelial cells. Biochem. Biophys. Res. Commun. 227: 35-40.

6. Clutterbuck, E. J., Hirst, E. M. and Sanderson, C. J. 1989. Human interleukin-5 (IL-5) regulates the production of eosinophils in human bone marrow cultures: comparisons and interactions with IL-1, IL-3, IL-6, and GM-CSF. Blood 73: 1504 1509.

7. Coyle, A. J., Ackerman, S. J., Burch, R., Proud, D. and Irvin, C. G. 1995. Human eosinophil-granule major basic protein and synthetic polycations induce airway responsiveness in vivo dependent upon bradykinin generation. J. Clin. Invest. 95: $1735-1740$.

8. Gonzaro, J. A., Jia, G. O., Aguirre, V., Friend,D., Coyle, A. J., Jenkins, N.A., Lin, G.-S., Katz, H., Lichtman, A., Copeland, N., Kopf, M. and Gutierrez-Ramos, J. C. 1996. Mouse eotaxin expression parallels eosinophil accumulation during lung allergic inflammation but is not restricted to a Th2 type response. Immunity 4: 1-14.

9. Holgate, S. T. 1993. Asthma-Pathophysiology. pp. 13.1-13.21. In: Allergy (Holgate, S.T. and Church, M.K. eds.), Gower Medical Publishing, London.

10. Hopp, R. J., Bewtra, A. K., Biven, R., Nair, N. M. and Wenley, T. R. G. 1988. Bronchial reactivity pattern in non-asthmatic parents of asthmatics. Ann. Allergy 61: 184-186.

11. Hopp, R. J., Townley, R. G., Biven, R. E., Bewtra, A. K. and Nair, N. M. 1990. The presence of airway reactivity before the development of asthma. Am. Rev. Respir. Dis. 141: 2-8.

12. Kumar, R. K. 1995. Experimental models in pulmonary pathology. Pathology 27: 130-132.

13. Li, X.-M., Schofield,B. H., Wang, Q.-F., Kim,K.-H. and Huang, S.-K. 1998. Induction of pulmonary allergic responses by antigen-specific Th2 cells. J. Immunol. 160: 1378-1384.

14. Matsuda, H., Watanabe, N., Geba, G. P., Sperl, J., Tsudzuki, M., Hiroi, J., Matsumoto, M., Ushio, H., Saito, S., Askenase, P. W. and Ra, C. 1997. Development of atopic dermatitis-like skin lesion with IgE hyperproduction in $\mathrm{NC} / \mathrm{Nga}$ mice. Int Immunol. 9: 461-466.

15. Matsumoto, M., Ra, C., Kawamoto, K., Sato, H., Itakura, A., Sawada, J., Ushio, H., Suto, H., Mitsuishi, K., Hikasa, Y. and Matsuda, H. 1999. IgE hyperproduction through enhanced 
tyrosine phosphorylation of Janus Kinase 3 in NC/Nga mice, a model for human atopic dermatitis. J. Immunol. 162: 10561063.

16. Motojima, S., Figas, E., Loegering, D. A. and Gleich, G. J. 1989. Toxicity of eosinophil cationic proteins for guinea pig tracheal epithelium in vitro. Am. Rev. Respir. Dis. 139: 801805.

17. Ohta, K., Yamashita, N., Tajima, M., Miyasaka, T., Nakano, J., Nakajima, M., Ishii, A., Horiuchi, T., Mano, K. and Miyamoto, T. 1999. Diesel exhaust particulate induces airway hyperresponsiveness in a murine model: Essential role of GM-CSF. $J$. Allergy Clin. Immunol. 104: 1024-1030.

18. Postma, D. S., Bleecker, E. R., Amelung, P. J., Holroyd, K. J., Xu, J., Panhuysen, C. I. M., Meyers, D. A. and Levitt, R. C. 1995. Genetic susceptibility to asthma-bronchial hyperresponsiveness coinherited with a major gene for atopy. New Engl. J. Med. 333: 894-900.

19. Robinson, D., Hamid, Q., Bentley, A., Ying, S., Kay, A. B. and Durham, S. R. 1993. Activation of CD4 ${ }^{+}$T cells, increased Th2-type cytokine mRNA expression, and eosinophil recruitment in bronchoalveolar lavage after allergen inhalation challenge in patients with atopic asthma. J. Allergy Clin. Immunol. 92: $313-324$

20. Rothenberg, M. E., MacLean, J. A., Pearlman, E., Luster, A. D. and Leder, P. 1997. Target disruption of the chemokine eotaxin partially reduces antigen-induced tissue eosinophilia. J. Exp. Med. 185: 785-790.

21. Salob, S. P. and Atherton, D. J. 1993. Prevalence of respiratory symptoms in children with atopic dermatitis attending pediatric dermatology clinics. Pediatrics 91: 8-15.

22. Sears, M. R., Burrows, B., Flannery, E. M., Herbison, G. P. and Hewitt, C. J. 1991. Relation between airway responsiveness and serum IgE in children with asthma and in apparently normal children. New Engl. J. Med. 325: 1067-1071.

23. Sehmi, R., Wood, L. J., Watson, R., Foley, R., Hamid, Q., O’Byme, P. M. and Denburg, J. A. 1997. Allergen-induced increases in IL-5 receptor $\alpha$-subunit expression on bone marrow-derived $\mathrm{CD} 34^{+}$cells from asthmatic subjects. A novel marker of progenitor cell commitment towards eosinophilic differentiation. J. Clin. Invest. 100: 2466-2475.

24. Seminario, M.-C. and Gleich, G. J. 1994. The role of eosinophils in the pathogenesis of asthma. Curr. Opin. Immunol. 6: 860-864.

25. Smith, H. 1992. Asthma, inflammation, eosinophils and bronchial hyperresponsiveness. Clin. Exp. Allergy 22: 187-197.

26. Strath, M., Warren, D. J. and Scanderson, C. J. 1985. Detection of eosinophil peroxidase assay. Its use as an assay for eosinophil differentiation factors. J. Immunol. Methods 83: 209-215.

27. Vestergaad, C., Yoneyama, H., Murai, M., Nakamura,K., Tamaki, K., Terashima, Y., Imai, T., Yoshie, O., Irimura, T., Mizutani, H. and Matsushima, K. 1999. Overproduction of Th2-specific chemokines in NC/Nga mice exhibiting atopic dermatitis-like lesions. J. Clin. Invest. 104: 1097-1105.

28. Watanabe, N., Kobayashi, A., Miyajima, H., Hirano, T. and Ovary, Z. 1987. Detection of IgE antibody-forming cells by passive cutaneous anaphylaxis using cell extract from lymphoid organs. J. Immunol. Methods 96: 41. 